\title{
GRANITOS DE PEDRA DE GUARATIBA, RJ: VARIAÇÕES FACIOLÓGICAS E EVIDÊNCIAS DE ACUMULAÇÃO DE MEGACRISTAIS POR SEGREGAÇÃO MECÂNICA EM ZONA DE ENCLAVES
}

\author{
GRANITES OF PEDRA DE GUARATIBA, RJ: FACIOLOGICAL VARIATIONS AND FIELD \\ EVIDENCES OF MEGACRYSTS ACCUMULATION BY MECHANICAL SEGREGATION IN \\ ZONE OF ENCLAVES
}

\author{
Soraya ALMEIDA, Carlos Wagner Rodrigues do NASCIMENTO \\ Universidade Federal Rural do Rio de Janeiro. Rodovia BR 465, Km 07, s/n Zona Rural, Seropédica - RJ. \\ E-mails: salmeida1966@gmail.com; carloswagner.geologia@yahoo.com \\ Introdução \\ O Maciço da Pedra Branca: caracterização geológica \\ Granitos em Pedra de Guaratiba \\ Relações entre aglomerados de feldspato e enclaves \\ Considerações Finais \\ Referências
}

\begin{abstract}
RESUMO - A Serra da Capoeira Grande e o Morro do Silvério, em Pedra de Guaratiba, constituem o prolongamento sudoeste do Maciço da Pedra Branca. A rocha dominante na região é um granito rosa com cristais de microclina tabular orientados na direção NESW. Variações faciológicas resultantes da irregularidade no tamanho de grãos, da razão fenocristais/matriz e da intensidade da lineação ocorrem em escala métrica a centimétrica e com contatos transicionais entre si. Enclaves de metassedimentos e de rochas ortoderivadas, com diferentes graus de assimilação, ocorrem ao longo de uma faixa linear NE-SW. Esses apresentam contornos lenticulares e orientação preferencial concordante com a direção dos megacristais de microclina e do bandamento ígneo. Dados de campo apontam para processos de segregação mecânica na formação dos subtipos, com granito equigranular, de granulação fina, como produto de segregação entre fenocristais e material intersticial. $\mathrm{O}$ arranjo espacial entre enclaves, granito equigranular e aglomerados de feldspato indicam terem os enclaves atuado como filtros retentores de fenocristais durante fluxo magmático. Concentrados de allanita ocorrem ao longo da zona enriquecida em enclaves, sugerindo a formação desse mineral por fluidos tardios, com mobilização de elementos terras raras favorecida pela maior permeabilidade da faixa.

Palavras-Chave: Granito; Pedra de Guaratiba; Maciço da Pedra Branca; enclaves; allanita.
\end{abstract}

\begin{abstract}
The Serra da Capoeira Grande and the Morro do Silvério in Pedra de Guaratiba constitute an southwest extension of the Pedra Branca Massif. The dominant rock is granite with NE-SW oriented crystals of tabular microcline of intense pink color. Faciological diversification occurs in metric to centimeter scale as a result of changes in grain size, phenocryst/matrix ratio or lineage intensity. The contacts between facies are always transitional. The enclaves have lenticular contours, with different degrees of assimilation and stretch orientation concordant with tabular microcline and igneous banding. Outcrop patterns suggest processes of mechanical segregation as the origin of subtypes, with fine-grained equigranular granite occurring as product of segregation between phenocrysts and interstitial material. Enclaves of metassediments and of ortho-derivative rocks occur along a linear NE-SW direction. Spatial arrangement among enclaves, equigranular granite and microcline clusters indicate that enclaves acted as filters during magmatic flow. Allanite concentrates occur along the enclave zone, presuming an origin of this mineral by fluid mobilization of rare earth elements in a structurally more permeable zone.
\end{abstract}

Keywords: Granite; Pedra de Guaratiba; Pedra Branca Massif; enclaves; allanite.

\section{INTRODUÇÃO}

O termo Maciço da Pedra Branca designa um conjunto de montanhas situado no centro da malha metropolitana da cidade do Rio de Janeiro e que ocupa uma área superior a $150 \mathrm{~km}^{2}$. Sua denominação é uma referência ao predomínio, entre suas rochas, de granitos de coloração clara. Pedra de Guaratiba, bairro localizado nas margens da Baia de Sepetiba, também tem sua designação relacionada a ocorrências de granitos que afloram na Serra da Capoeira Grande e no Morro do Silvério, elevações que constituem um prolongamento do Maciço da Pedra Branca (Figuras 1, 2).
O mapa geológico do estado da Guanabara, em escala 1:50.000, de Helmbold et al. (1965), não apresenta aspectos petrográficos da localidade e os estudos realizados por Porto Junior (1994) e Ferrari (2001) restringem-se à Pedreira SIMGRA (Sociedade Industrial de Mineração de Granitos), situada na borda sudoeste da Serra da Capoeira Grande.

A malha urbana e as matas fechadas nas áreas de proteção ambiental dificultam o acesso aos afloramentos. À beira-mar, as construções também ocultam parcialmente as rochas, pois devido ao 
alagamento permanente da zona de baixada, as casas estão instaladas sobre as rochas que margeiam a baía (Figura 3). Assim, a despeito do número de instituições geológicas na cidade, a região de Pedra de Guaratiba, assim como muitas áreas da cidade do Rio de Janeiro, não possuía, até o momento, de dados de mapeamento em escala detalhe.

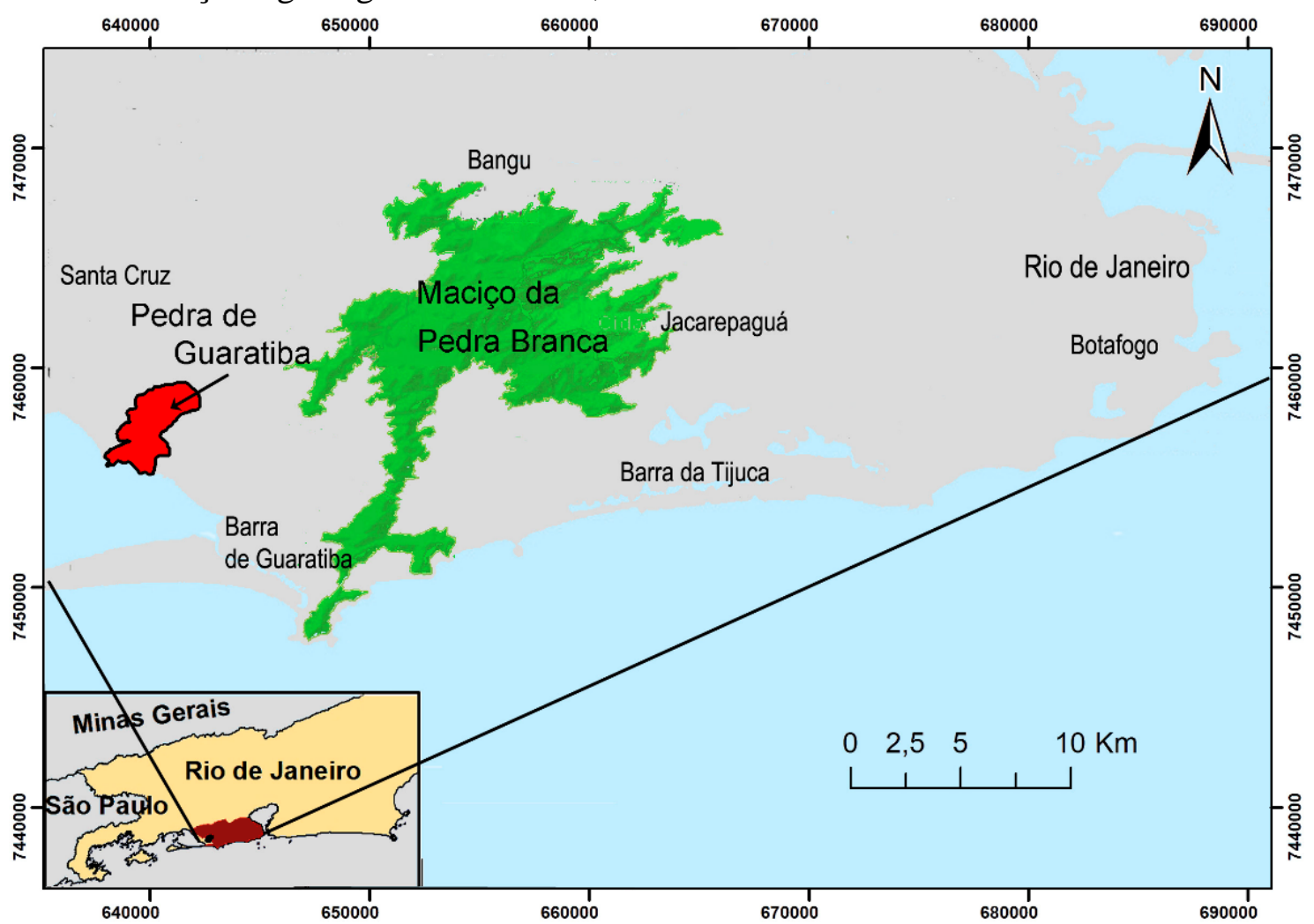

Figura 1 - Localização da área estudada, destacada em vermelho, e sua posição relativamente ao Maciço da Pedra Branca.

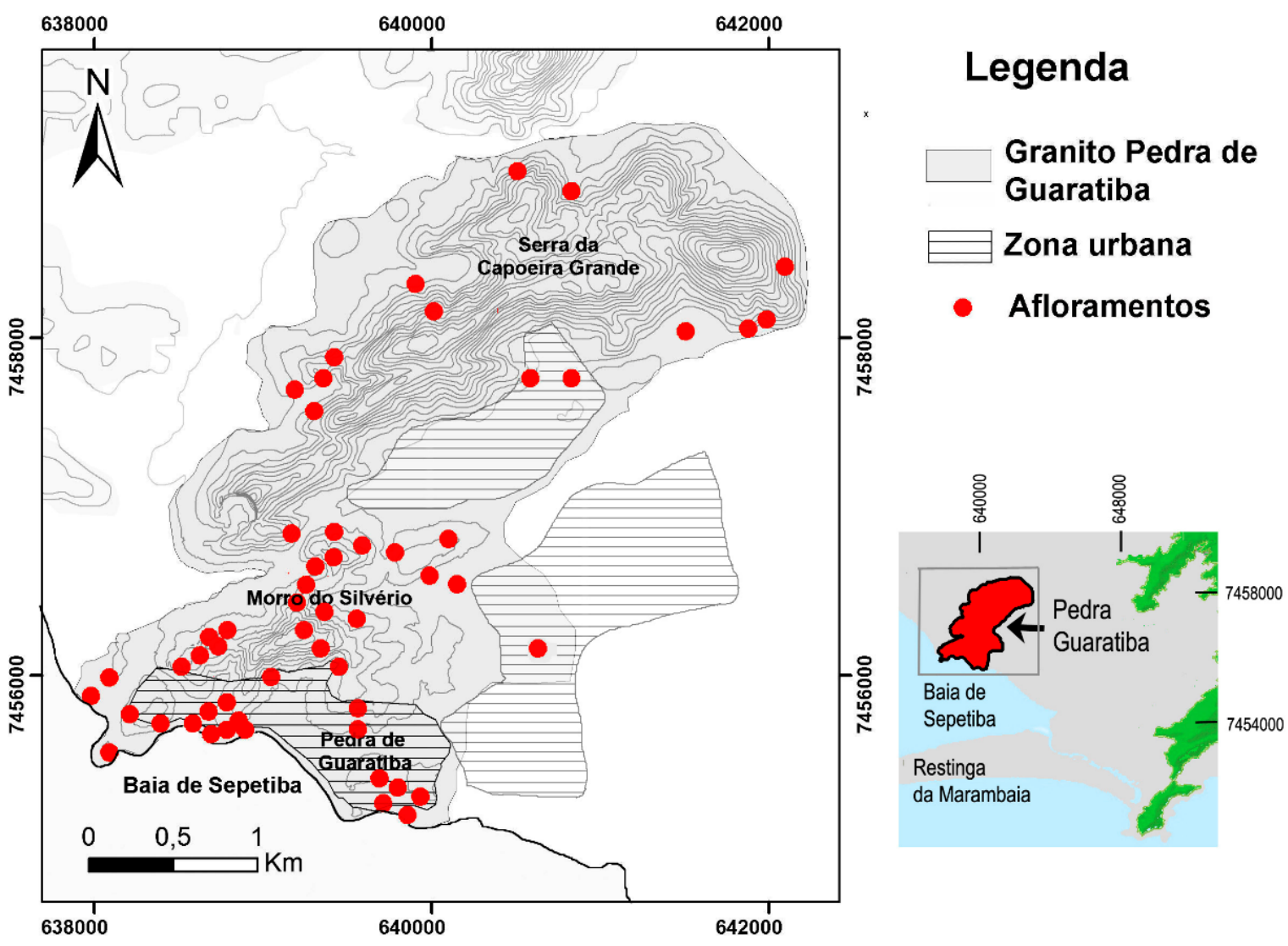

Figura 2 - Serra da Capoeira Grande e Morro do Silvério -Pedra de Guaratiba. 


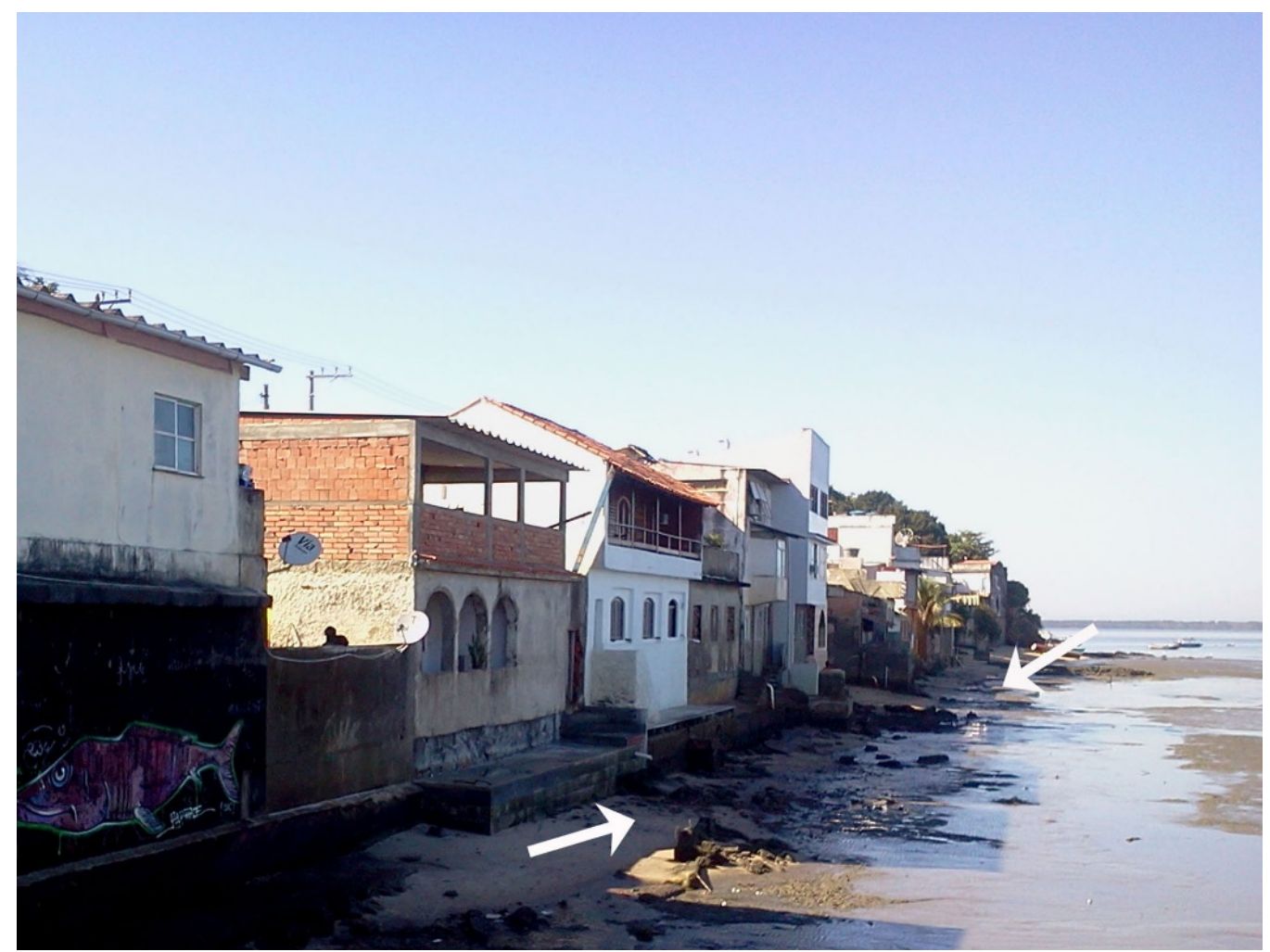

Figura 3 - Construções típicas sobre afloramentos na costa de Pedra de Guaratiba.

\section{O MACIÇO DA PEDRA BRANCA: CARACTERIZAÇÃO GEOLÓGICA}

Segundo Porto Junior (1994, 2004), o Maciço da Pedra Branca é constituído, predominantemente, por granitoides gerados e/ou retrabalhados na Orogênese Brasiliana. As rochas mais antigas do maciço compõem uma unidade paraderivada formada por gnaisses semipelíticos e pelíticos, com intercalações de quartzitos, calciossilicáticas e anfibolitos. Ortognaisses pré a sin-colisionais, de composição tonalítica a diorítica, ocorrem intrusivos no conjunto metassedimentar.

Ambos, metassedimentos e ortognaisses, são cortados por leucogranitoides gerados por fusão de tipos graníticos mais antigos. Por fim, o conjunto foi intrudido por magmas básicos a intermediários, gabro a monzodioríticos e ácidos, granodioríticos a graníticos.

A ausência de deformação nas rochas graníticas indicaria um caráter pós-colisional. Segundo Porto Junior (1994), o conjunto de granitoides do Complexo Granítico Pedra Branca contêm quatro unidades distintas, da mais antiga para a mais jovem: Tonalítica, Granito Pedra Branca, Biotita Granito e Leucogranítica.

A Unidade Tonalítica, composta por rochas básicas a intermediárias, aflora principalmente na parte central do maciço e pontualmente em outras regiões. Suas rochas possuem coloração cinza e grande variação textural. Essa unidade inclui tonalitos, gabros, dioritos, quartzo dioritos e granodioritos que, em geral, estão pouco ou nada deformados e podem conter enclaves.

A Unidade Granito Pedra Branca, de maior expressão territorial, é composta por sieno e monzogranitos rosados a esbranquiçados que se apresentam em quatro fácies distintas: Fácies Médio-Homogênea, Fácies Pegmatítica, Fácies Hololeucocrática e Fácies Bandada.

A Fácies Média-Homogênea, dominante na unidade, é caracterizada, como o próprio termo indica, por relativa homogeneidade textural, contendo microclina de até $2 \mathrm{~cm}$.

A Fácies Bandada é caracterizada por exibir foliação conspícua definida por orientação de megacristais de microclina de até $7 \mathrm{~cm}$ e por conter bandas enriquecidas em biotita.

A Fácies Hololeucocrática ocorre como bandas de granito equigranular de coloração branca, com 5 a 60 centímetros de espessura e dezenas de metros de comprimento, intercaladas na Fácies MédiaHomogênea.

A Fácies Pegmatítica é definida por bolsões ou diques subconcordantes à estrutura do granito, com mais de $70 \%$ de megacristais de microclina que chegam a 12 centímetros de comprimento.

A Unidade Biotita Granito ocorre como corpos tabulares de pequenas dimensões, subhorizontais, o que dificulta sua individualização em mapa. É composta por biotita granito 
(monzogranito) de cor cinza, exibindo uma Fácies Porfirítica e uma Fácies Equigranular identificada com o Granito Favela descrito por Pires et al. (1982).
A Unidade Leucogranítica é formada por diques subverticais de álcali-granitos com espessura entre 15 e $50 \mathrm{~cm}$ alojados em zonas de fratura.

\section{GRANITOS EM PEDRA DE GUARATIBA}

A caracterização dos granitos de Pedra de Guaratiba realizada por Porto Junior (1994) limita-se às rochas aflorantes na Pedreira SIMGRA, no extremo sudoeste da Serra da Capoeira Grande. A pedreira, atualmente desativada, iniciou suas atividades em 1962 e hoje se apresenta como um paredão escalonado com aproximadamente $80 \mathrm{~m}$ de altura. Porto Junior (1994) a descreve como constituída por granitos homogêneos, com megacristais de microclina com até $2 \mathrm{~cm}$, dispersos em matriz granodiorítica com biotita.

Segundo Porto Junior (1994) essas rochas são identificadas como pertencente à Fácies MédiaHomogênea da Unidade Granito Pedra Branca, que gradam para Fácies Bandada, de ocorrência subordinada na pedreira, e cuja foliação resulta de leitos mais ricos em biotita e de concentrações de megacristais orientados de microclina. $\mathrm{O}$ autor reconhece uma porcentagem relativamente maior de biotita na Fácies Bandada, quando comparada à Fácies
Média-Homogênea, assim como a existência de aglomerados isolados de minerais máficos com até $2 \mathrm{~cm}$, que são interpretados como restos de enclaves assimilados. Observa, também, ocorrência da Fácies Pegmatítica, sob a forma de bolsões.

Nas demais áreas do bairro, fora do âmbito da pedreira, rochas correlacionáveis às fácies Média-Homogênea, Bandada e Pegmatítica, definidas por Porto Junior (1994) no âmbito do Maciço da Pedra Branca, apresentam contatos gradacionais entre si e estão associadas em escala métrica a centimétrica, o que impossibilita sua individualização em mapa. O tipo dominante, aqui designado Granito Pedra de Guaratiba para fins de descrição, é um granito hololeucocrático com cristais tabulares orientados de microclina envolvidos por uma matriz de granulação fina a média. Variações granulométricas ou composicionais definem bandas com conteúdo distintos de biotita e/ou diferentes razões megacristais/ matriz (Figuras 4A, B).
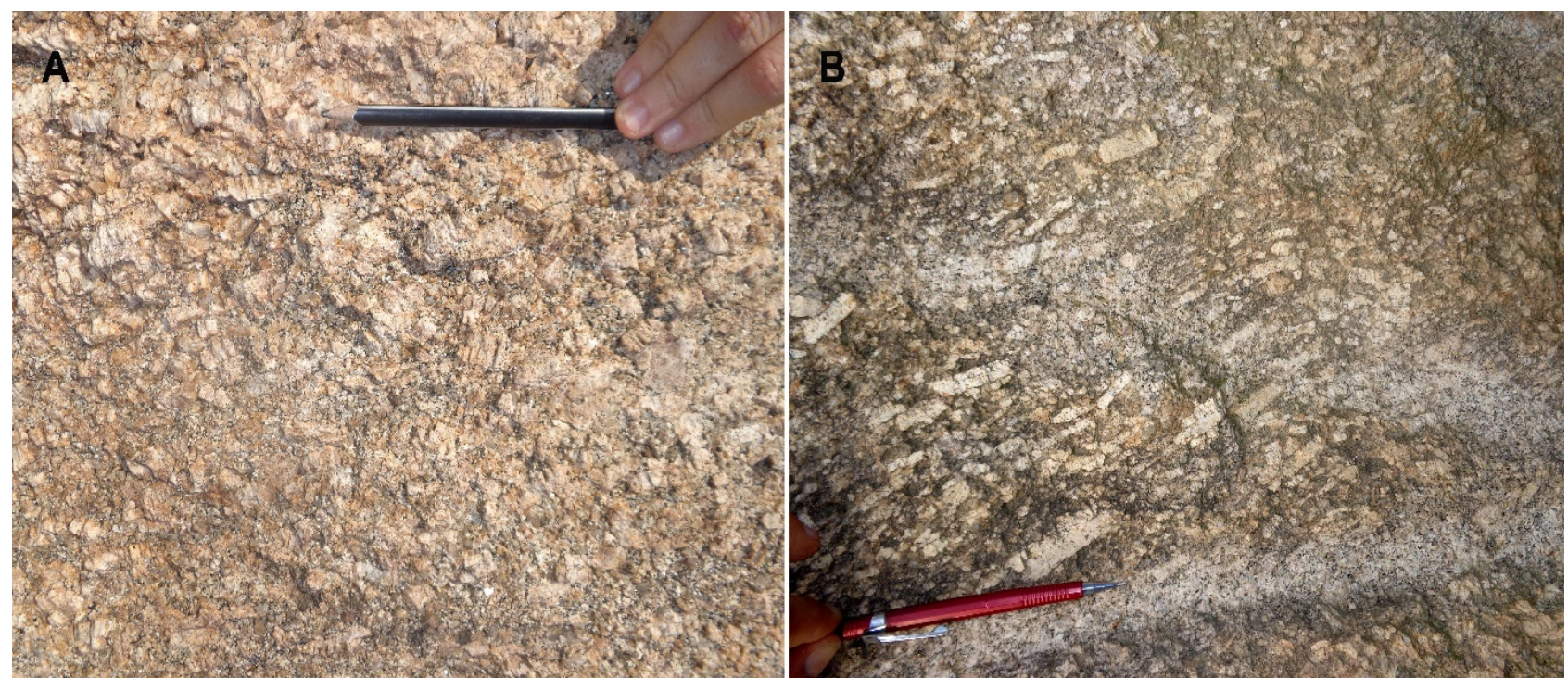

Figura 4 - A) Bandamento resultante de variação granulométrica. B) Lineação de microclina: feição característica dos granitos em Pedra de Guaratiba.

Os grãos de feldspato potássico orientados exibem 2 a $4 \mathrm{~cm}$ de comprimento, em média, mas não raro ultrapassam $5 \mathrm{~cm}$. Esses apresentam marcante lineação NE-SW, com valores médios ao redor de $\mathrm{N} 38^{\circ} \mathrm{E}$ e ampla variação de ângulos de mergulho, com caimento para SW e, secundariamente, para NE. O conteúdo de megacristais de microclina varia entre $40 \%$ e
60\%. A matriz possui textura granular e composição granodiorítica, com até $5 \%$ de biotita. Zircão, apatita, allanita e minerais opacos ocorrem como minerais acessórios.

Quanto maior o volume de megacristais na rocha, mais expressiva é a lineação da microclina. Bandas enriquecidas em biotita, com poucos milímetros de espessura, acompanham a 
lineação dos feldspatos. Mesmo quando dispersa, ou seja, fora das faixas de concentração, biotita exibe orientação planar concordante ao bandamento. Associado ao Granito Guaratiba, ocorrem granitos equigranulares, disposto em ao longo de faixas ou como bolsões irregulares. Trata-se de uma rocha hololeucocrática, com predomínio de grãos entre 1 a 2 mm de coloração cinza a rósea, rósea amarelada nos tipos mais intemperizados. A rocha padrão contém em torno de 3 a $5 \%$ de biotita e possui minerais opacos, zircão e allanita como minerais acessórios. Entretanto, os granitos equigranulares não formam uma unidade composicionalmente homogênea, pois exibem variações composicionais locais em sua moda.

Aglomerados de microclina ocorrem como bolsões de contornos irregulares e com contato transicional com a encaixante (Figura 5A). As dimensões dos megacristais de feldspato potássico nos aglomerados variam, em média, entre 4 e $10 \mathrm{~cm}$, podendo chegar a $15 \mathrm{~cm}$, resultando em uma rocha de aspecto pegmatítico (Figura 5B). O incremento da porcentagem de microclina é, frequentemente, acompanhado do aumento do tamanho dos grãos.

O Granito Pedra de Guaratiba exibe enclaves com dimensões variando de poucos centímetros a mais de dois metros e com ampla variedade de composição e textura (Figura 6).

Esses possuem contornos lenticulares, simétricos ou assimétricos, com direção de maior comprimento acompanhando a lineação dos megacristais de microclina da encaixante (Figura $6 \mathrm{~A}$ ), por vezes envolvidos por foliação de fluxo (Figura 6B).
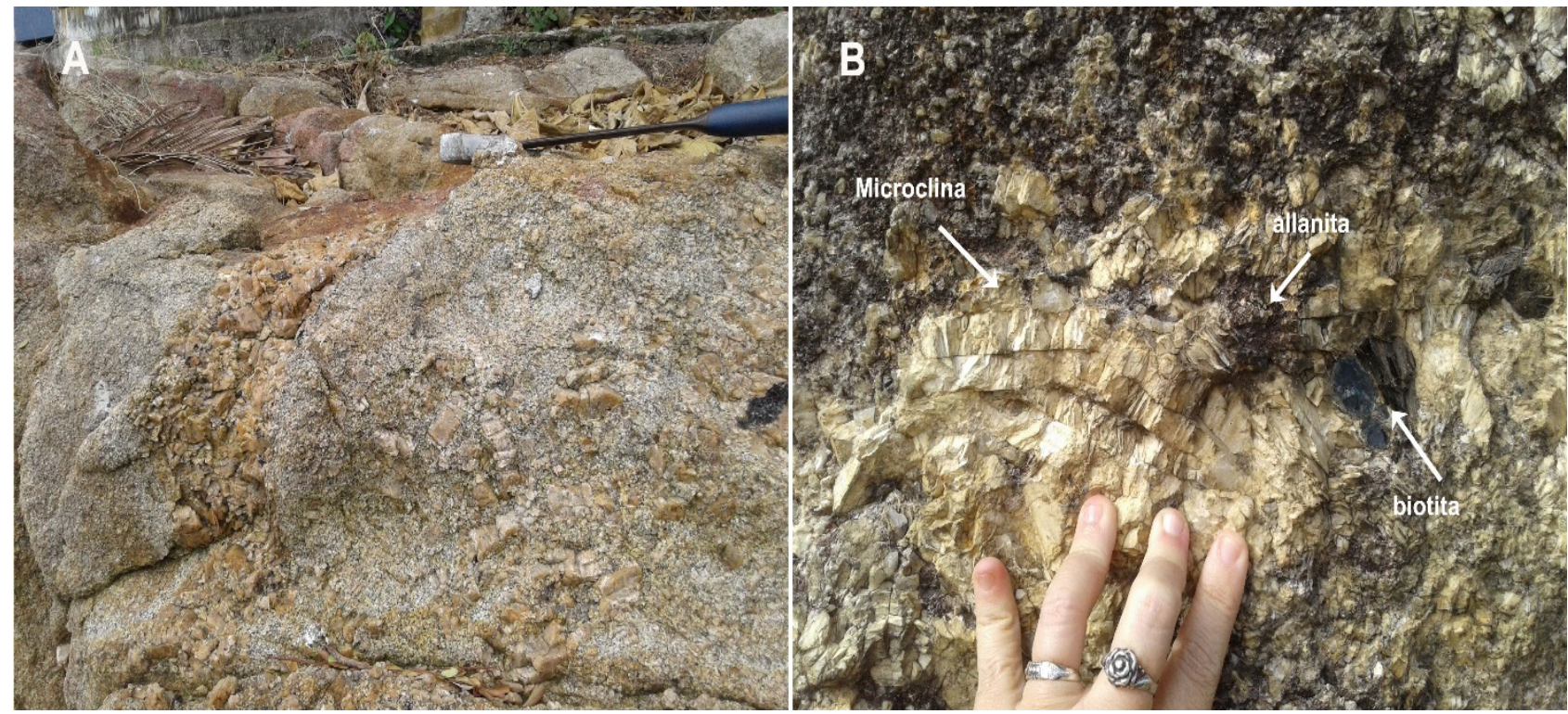

Figura 5 - A) Aglomerados de microclina: contatos gradacional com encaixante. B) Aspecto pegmatítico de aglomerado de microclina em contato gradacional com encaixante.

Enclaves de gnaisses porfiroclásticos com microclina ocelar envolvida por matriz diorítica são pouco frequentes (Figura 6C). Esses exibem diferentes graus de deformação e são correlatos a rochas do embasamento descritas por Almeida (2015) no Morro do Cruzeiro, no bairro de Santa Cruz, a noroeste de Pedra de Guaratiba. Megaenclaves de metassedimentos ocorrem no encontro do Morro do Silvério com a porção sul da Serra da Capoeira Grande e no extremo nordeste da mesma serra. São compostos por biotita gnaisses quartzosos intercalados com quartzito (Figura 6D).

Enclaves de gnaisses migmatíticos são abundantes, sendo possível, muitas vezes, observar no granito fitas de biotita contínuas à foliação do enclave, indicando assimilação de bordas (Figuras 7, 8).

Allanita é um mineral acessório em todos os granitos de Pedra de Guaratiba. Tipicamente são grãos subédricos a euédricos de até $2 \mathrm{~mm}$, não raro com mais de mais de $1 \mathrm{~cm}$ (Figura 9A). No Morro do Silvério, os cristais centimétricos de allanita ocorrem associados à megacristais aglutinados de microclina (Figura 9B). As zonas enriquecidas em allanita são facilmente identificadas pela presença de manchas avermelhadas, de poucos centímetros a mais de um metro (Figura 9B). Tais manchas ocorrem tanto no Granito Pedra de Guaratiba, como nos granitos equigranulares e são abundantes nas zonas de contato entre essas rochas. 

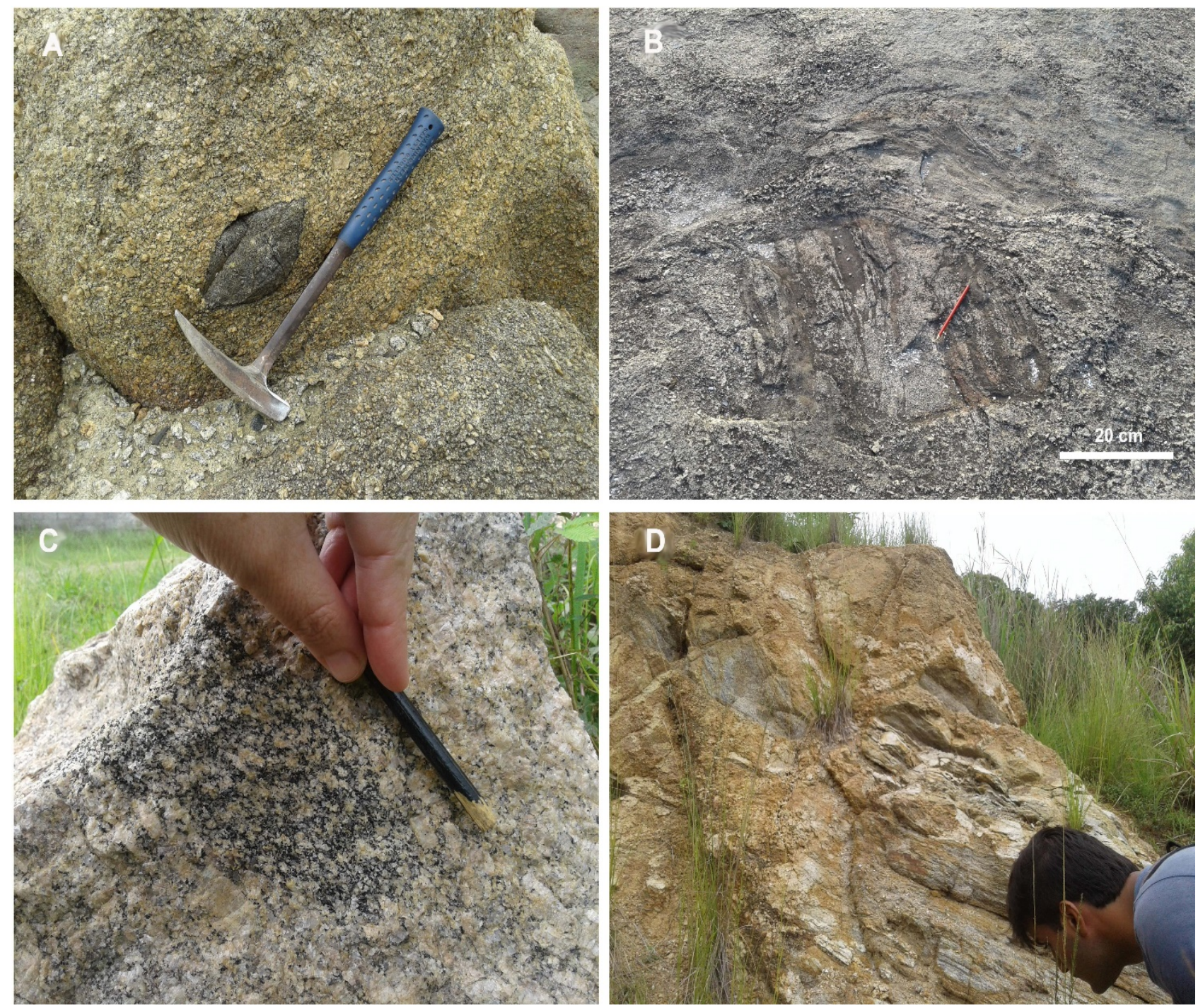

Figura 6 - Enclaves de diferentes composições em granitos de Pedra de Guaratiba. A) Enclave máfico de contorno simétrico; B) Enclave assimétrico de gnaisse migmatítico contornado por foliação de fluxo; C) Enclave de gnaisse porfiroclástico; D) Megaenclave de rocha metassedimentar.
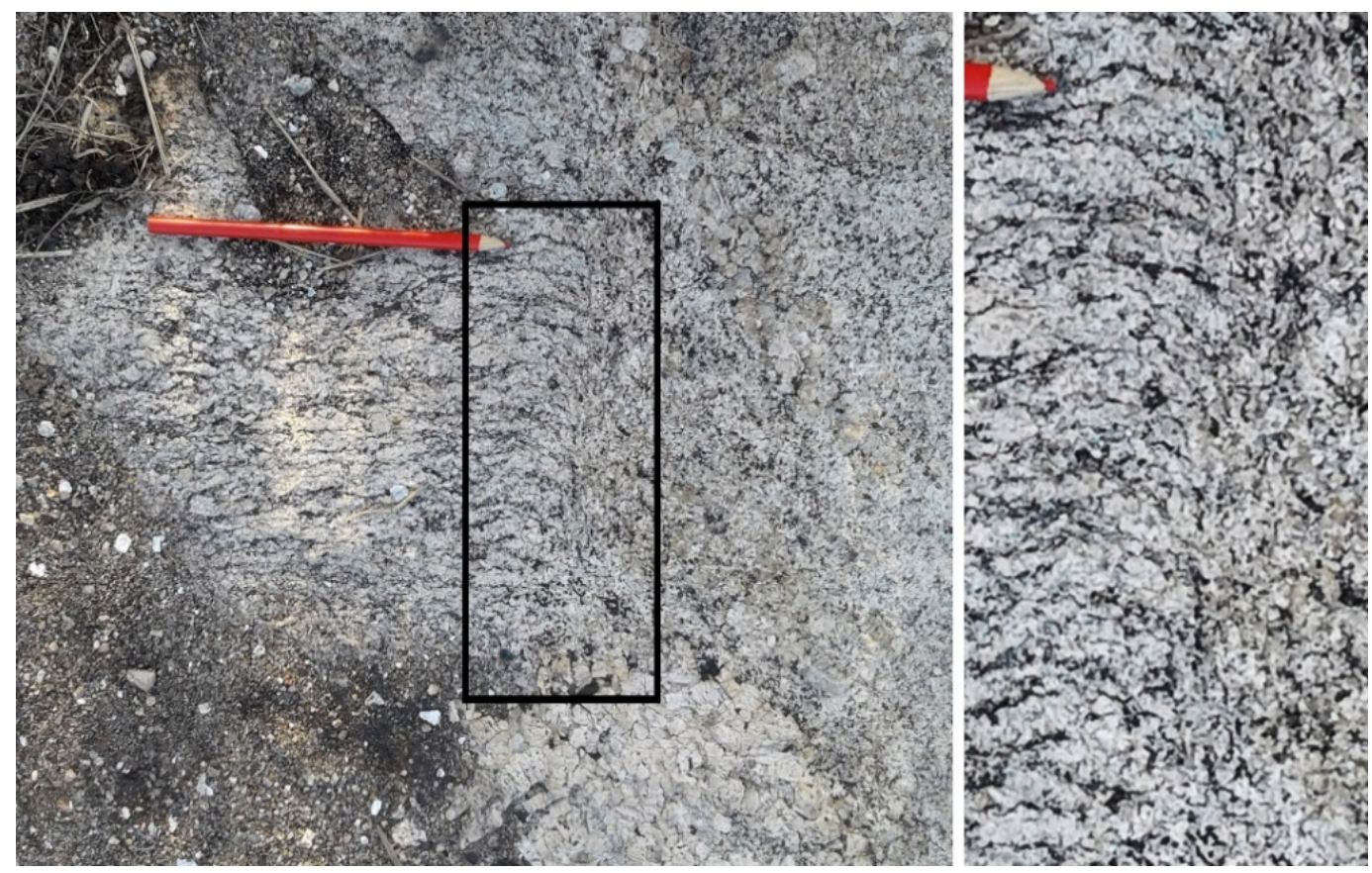

Figura 7 - Enclave com borda assimilada exibindo relictos da foliação no granito encaixante. O padrão, destacado na imagem à direita, sugere assimilação com componente cisalhante. 


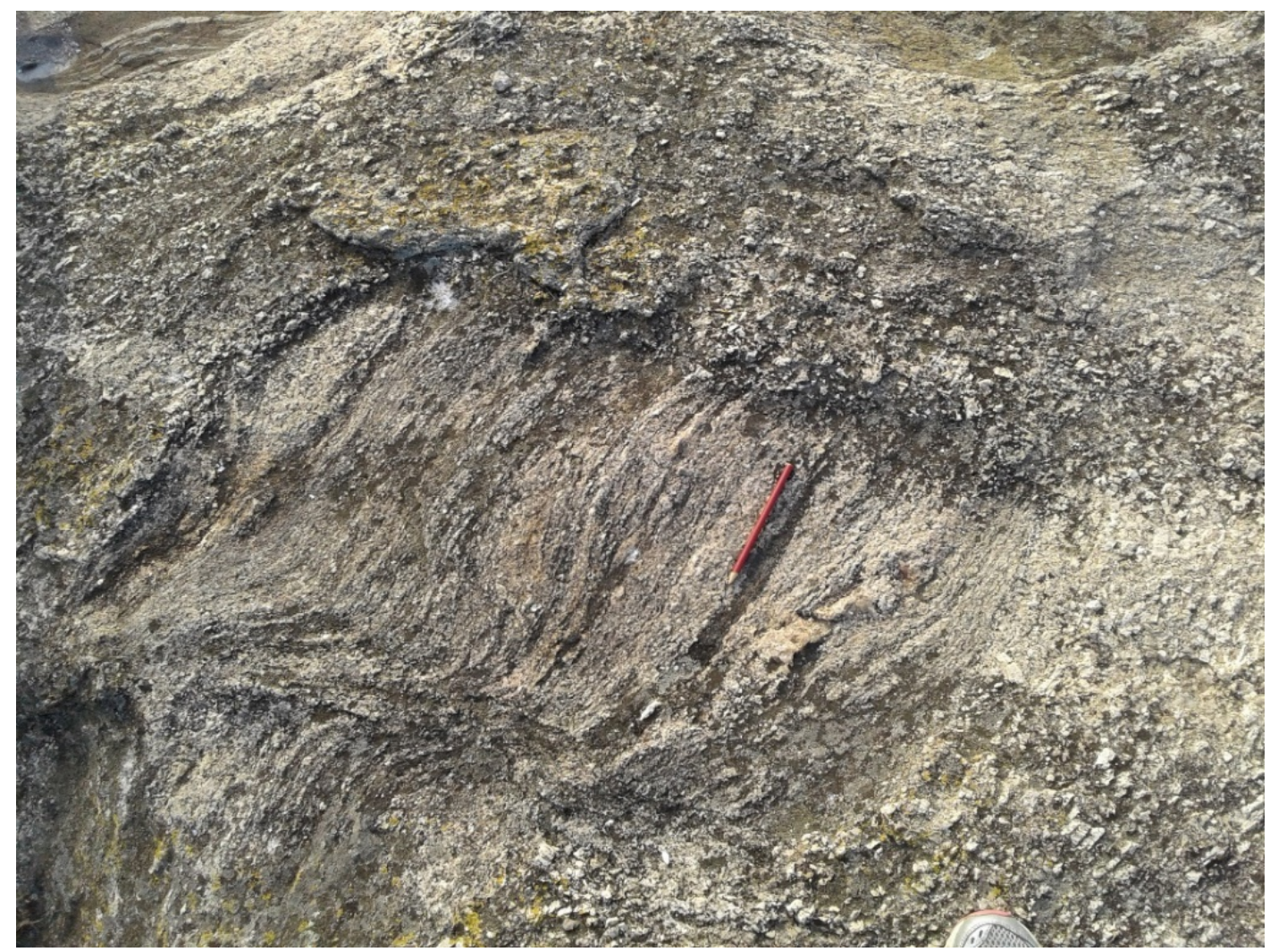

Figura 8 - A) Enclave de gnaisse com direção de alongamento e foliação paralela à direção de fluxo do granito encaixante.

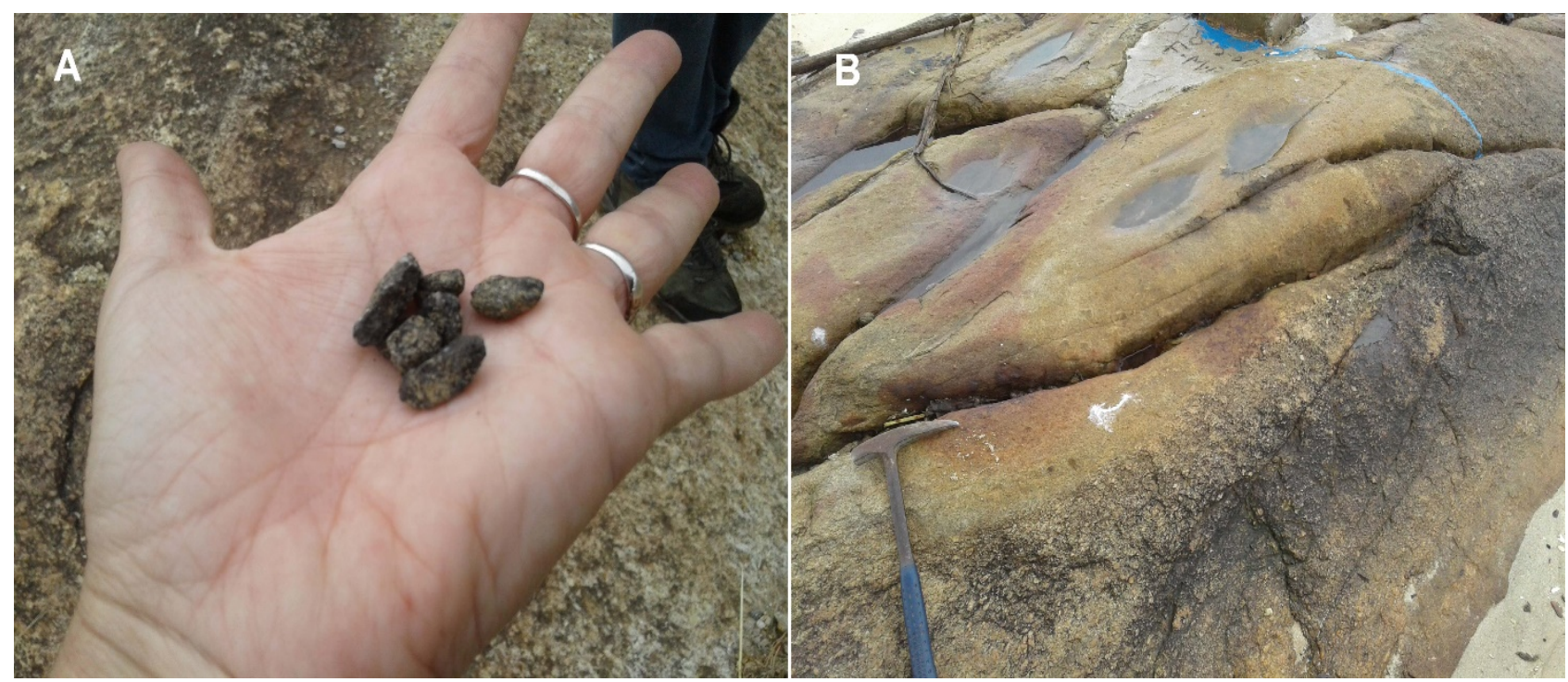

Figura 9 - A) Cristais centimétricos de allanita. B) Manchas avermelhadas características das zonas de enriquecimento em allanita.

Os granitos de Pedra de Guaratiba exibem uma direção preferencial de fraturamento NESW, com mergulhos verticais ou subverticais para SE e, secundariamente, para NW (Figura 10A). Com menor frequência, ocorrem fraturas de direção NW-SE, com mergulho principal para SW. A percolação de água ao longo das direções dominantes de fraturamento é responsável pela formação de blocos e matacões por processo de esfoliação esferoidal (Figura 10B).

Diques compostos por rochas afaníticas são frequentes ao longo das zonas de fratura, com espessura variando entre $10 \mathrm{~cm}$ e $2 \mathrm{~m}$. Quando pouco alterados, possuem coloração cinza a preta. Os tipos intemperizados exibem maior variedade de cores (castanho, verde, cinza esbranquiçado ou arroxeado). Foram identificados traquitos, fonolitos e lamprófiros, com ampla variação textural. Os diques com direção NW-SE, menos frequentes, normalmente ocorrem bifurcados aos diques da direção dominante (Figura 11). 


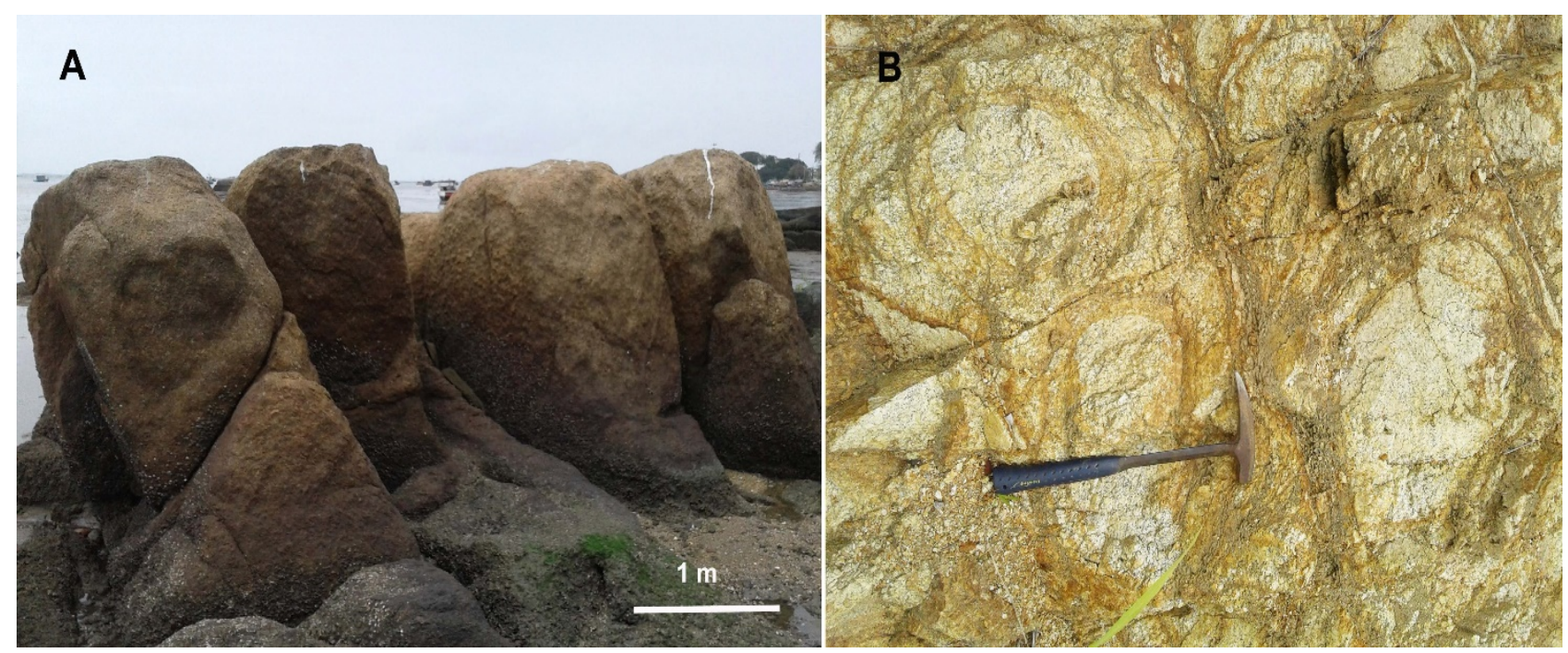

Figura - 10 A) Padrão de fraturamento NE-SE (dominante) e NW-SW em granito. B) Esfoliação esferoidal decorrente da percolação de água ao longo de fraturas.

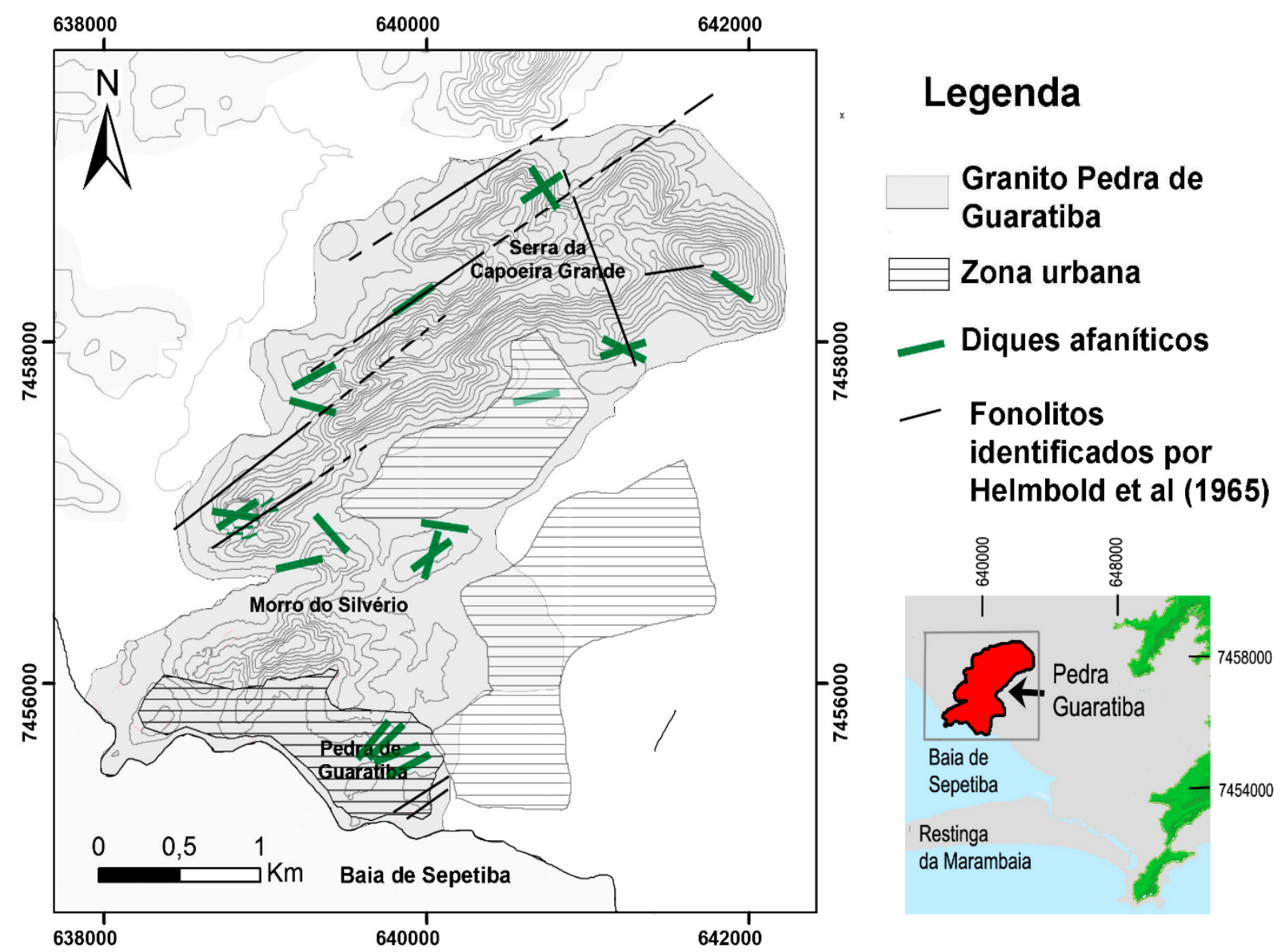

Figura 11 - Distribuição de diques máficos afaníticos em Pedra de Guaratiba.

Os contatos entre diques e granitos são retilíneos, com incorporação de fragmentos da rocha encaixante granítica junto às bordas. Exceção ocorre em zonas de megaenclaves, onde foram encontrados diques com padrão sinuoso acompanhando a foliação dos gnaisses. Um dique composto semelhante ao descrito por Ferrari (2001) na Pedreira Singra, com espessura em torno de $80 \mathrm{~cm}$, aflora na Rua Dalva de Oliveira (Figura 12A). A intrusão dupla é identi- ficada pela diferença de coloração entre as duas rochas e pela presença de enclaves do dique mais antigo na intrusão tardia. Assim como no afloramento descrito por Ferrari (2001), o dique encaixante exibe vênulas preenchidas com sílica (Figura 12B). Vênulas de sílica são também observadas em fragmentos de diques na base leste do Morro Redondo, no extremo noroeste da Serra da Capoeira Grande, dando à rocha um aspecto foliado. 

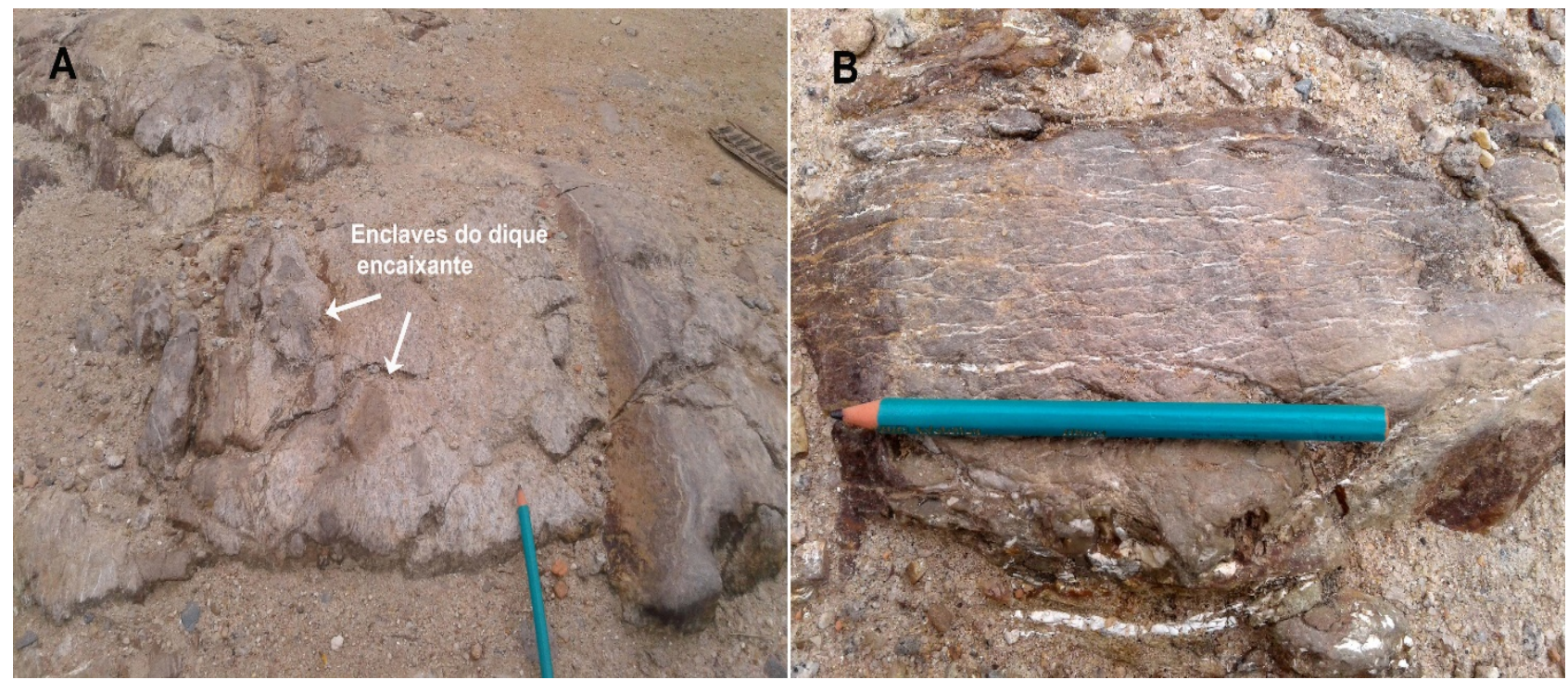

Figura 12 - A) Dique composto com enclaves do dique hospedeiro junta às bordas. B) Vênulas de sílica em dique com intrusão dupla.

\section{RELAÇÃO ENTRE AGLOMERADOS DE FELDSPATO, ENCLAVES E ALLANITA}

Aglomerados de feldspato potássico e granito equigranular ocorrem associados a enclaves ao longo de uma faixa que margeia a borda sul da Serra da Capoeira (Figuras 13).

$\mathrm{O}$ arranjo entre eles (Figura 14) sugere um processo mecânico para a formação dos agregados de microclina, com enclaves atuando como filtros que separam cristais de maior granulometria (material retido) do material intersticial, como proposto por Pinotti et al. (2016) para estruturas semelhantes em granitos de Sierras de Córdoba, Argentina.

A figura 15 é particularmente ilustrativa do processo mecânico proposto, pois a direção de corte, subparalela à direção de fluxo e perpendicular ao acamamento, mostra aglomerado e granito equigranular em lados opostos do enclave.

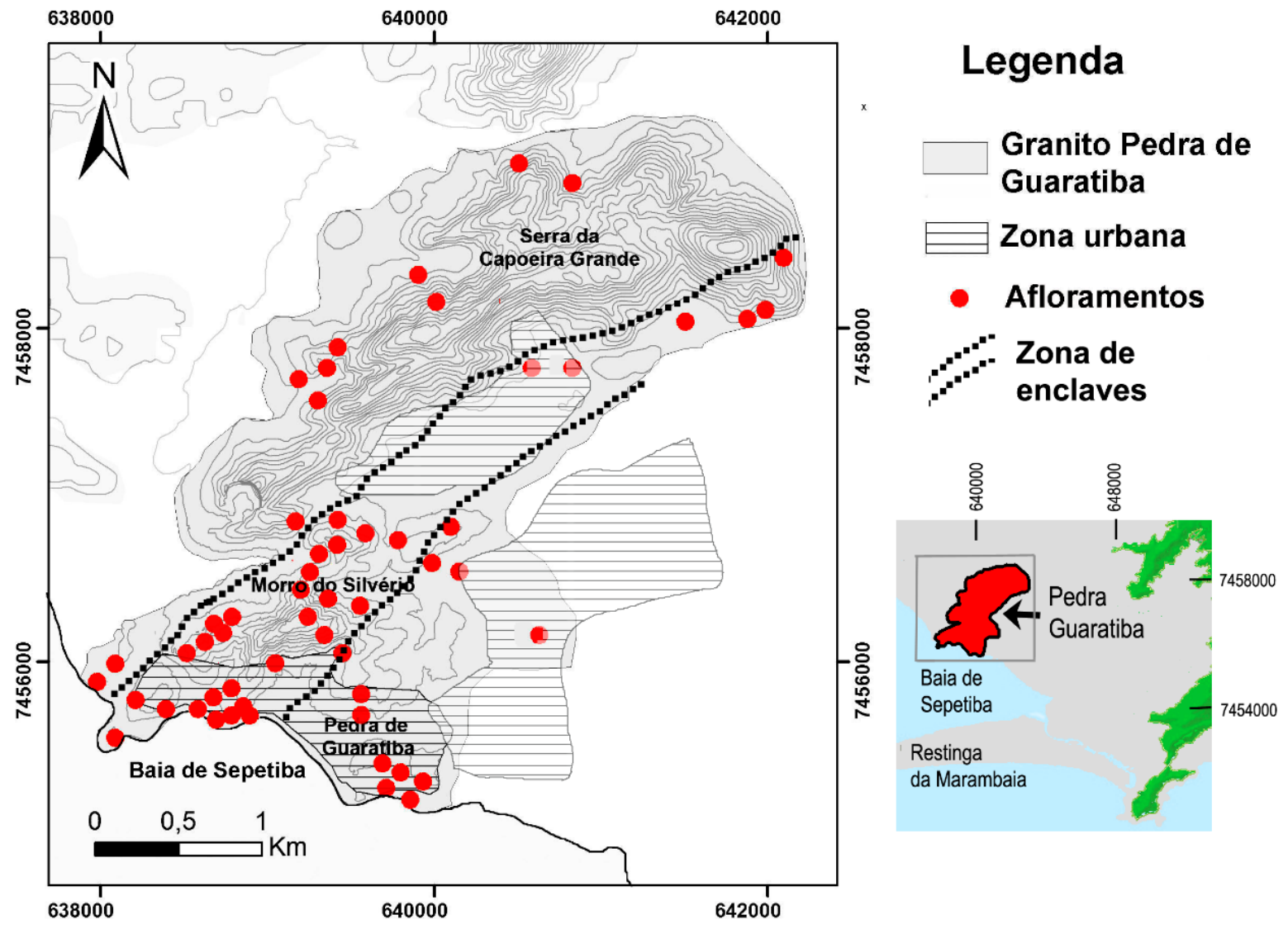

Figura 13 - Faixa de ocorrência de enclaves. 

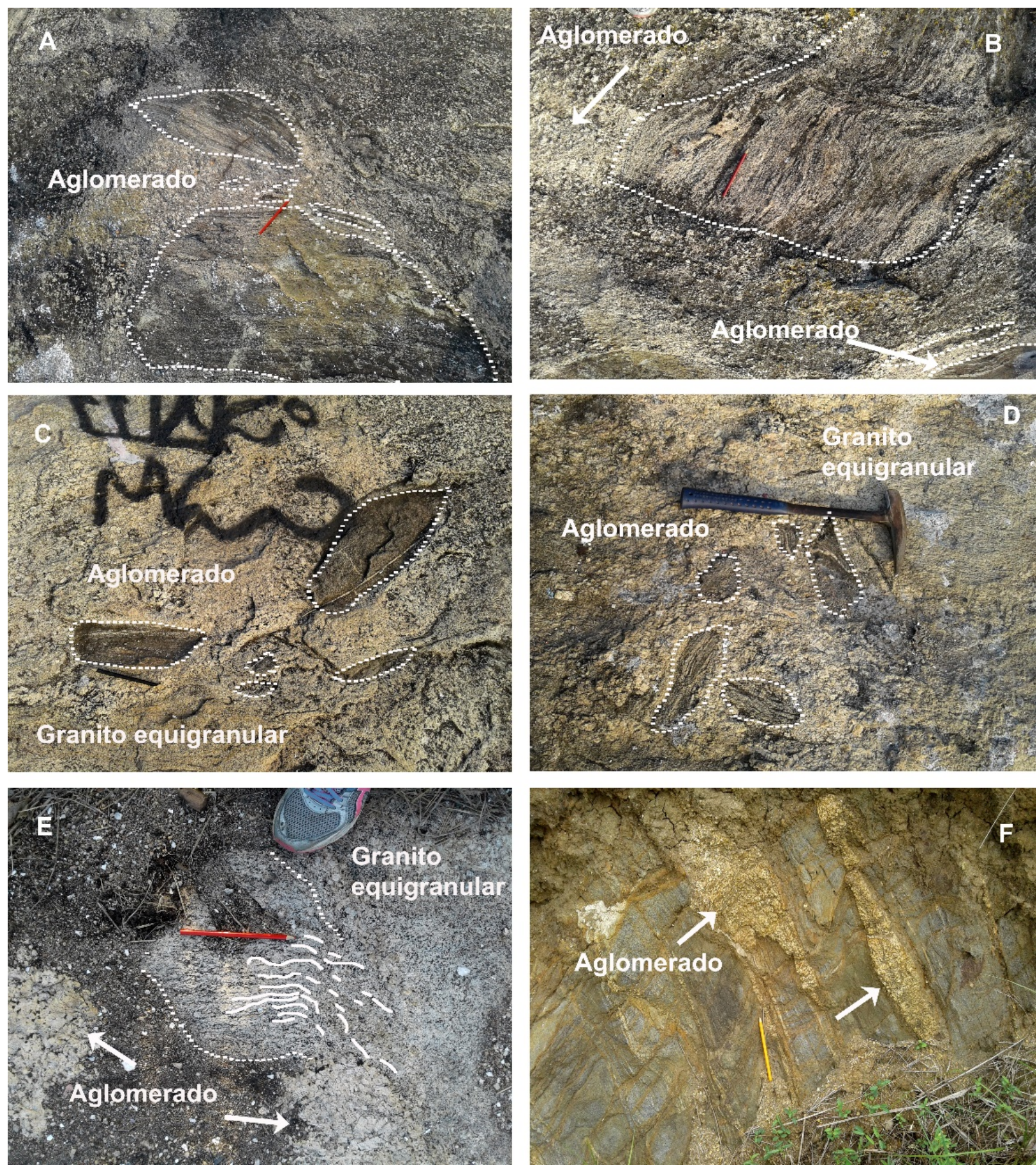

Figura 14 - Relações entre enclaves, aglomerados de megacristais e granito equigranular em diferentes direções de cortes. A e B) Aglomerados de megacristais adjacentes a enclaves. D, E, F) Enclaves entre aglomerados de megacristais e granito equigranular. E) com ilustração esquemática do prolongamento da foliação gnáissica sobre o granito. D) Aglomerados interdigitados com megaenclave de metassedimentos.

A direção dominante de lineação dos cristais tabulares de microclina em Pedra de Guaratiba exibe uma inflexão para leste que acompanha a assimetria dos enclaves (Figura 16).

Rocher et al. (2018) descrevem feições semelhante na intrusão de Asha, também na Argentina, onde aglomerados associados a enclaves achatados são abundantes na base do corpo ígneo. Segundo os autores, a origem da associação estaria relacionada à atuação de fluxos descendentes que agrupariam enclaves e megacristais, com a fusão sendo removida mecanicamente por filter pressing, sendo o fluxo uma resposta a variações termais durante estágios de cristalização e resfriamento.

Moyen et al. (2010) interpretam associação entre enclaves e megacristais ao longo de uma faixa no Granito Closept, no sul da Índia como antigos canais de transporte de magma. Assim como em Pedra de Guaratiba, os eixos maiores dos enclaves coincidem com a lineação dos megacristais e com a foliação dominante nas 


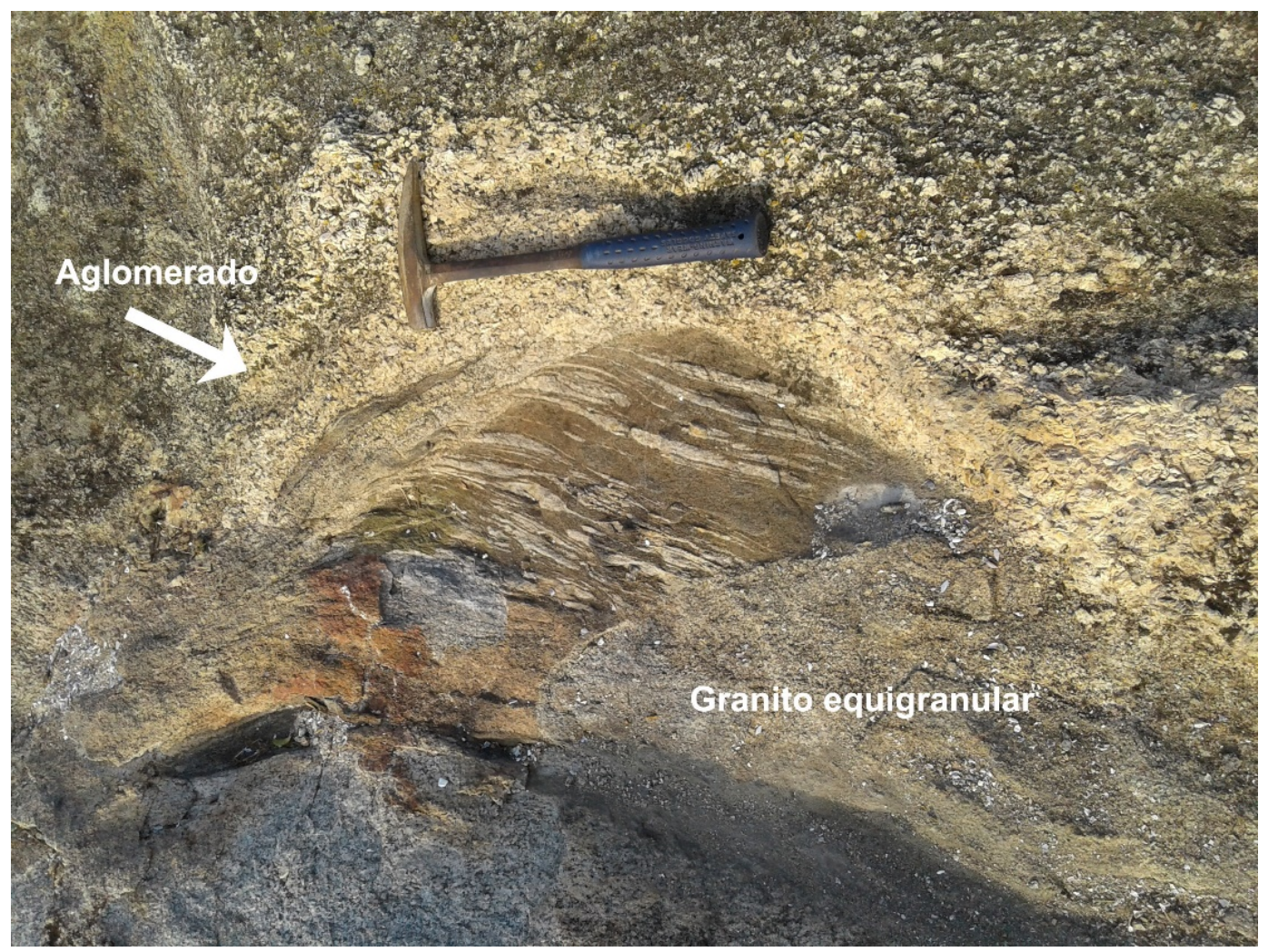

Figura15 - Aglomerado de feldspato potássico e granito equigranular em lados opostos de enclave assimétrico.

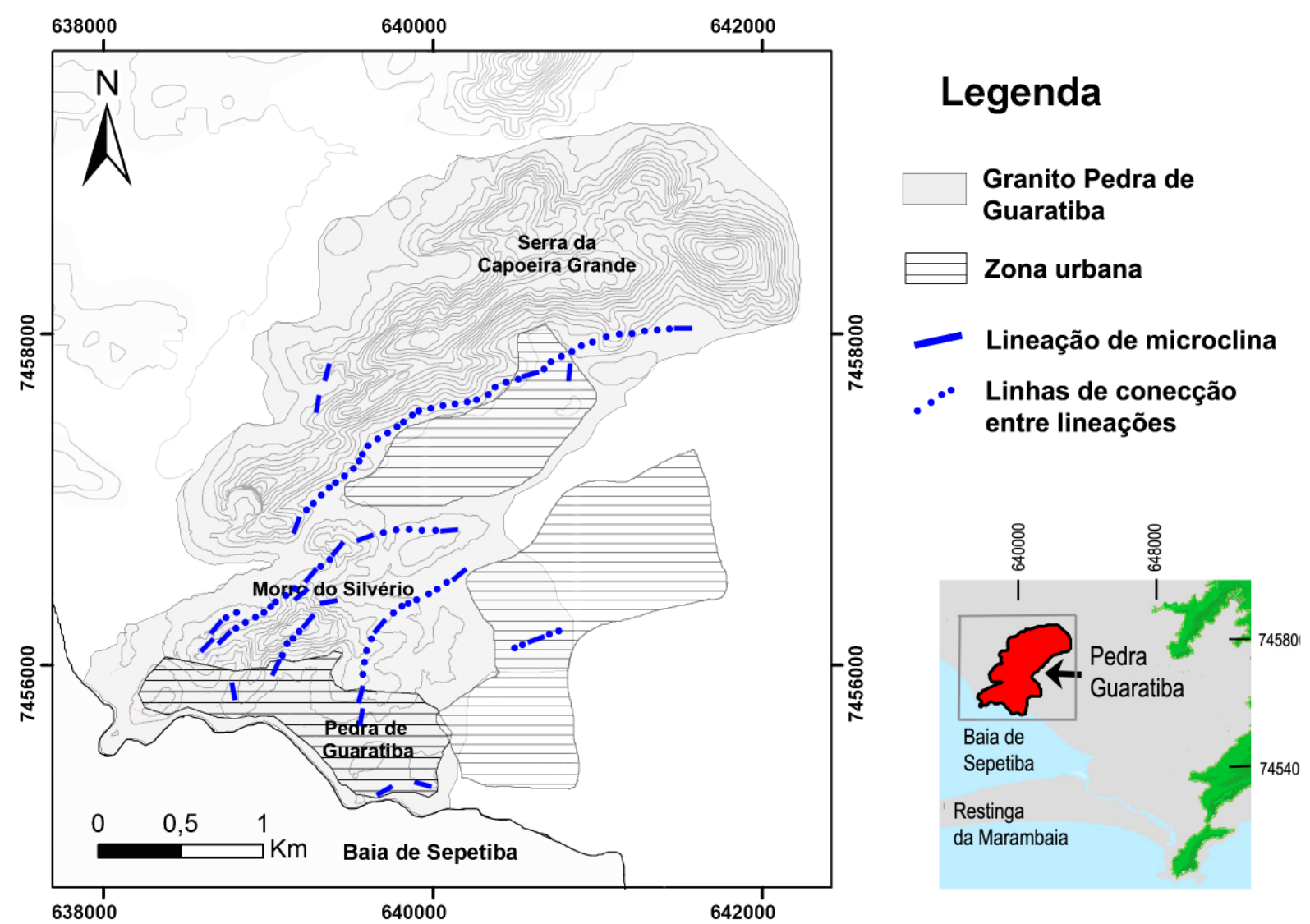

Figura 16 - Representação esquemática da distribuição da lineação de microclina tabular.

encaixantes gnáissicas. Tal arranjo estrutural resultaria da introdução de magma em zona de cisalhamento tectonicamente ativa.

A proposta de Moyen et al. (2010) se baseia no fato do Granito Closepet possuir um perfil de exposição superior a $10 \mathrm{~km}$, abrangendo uma zona crustal que varia de fácies granulito a xistoverde, o que permite avaliar o comportamento do 
magma em diferentes profundidades. Os autores notam que a porção mais profunda do corpo, onde se deu a penetração de magma ao longo de zona de cisalhamento é texturalmente heterogênea, rica em enclaves e em megacristais orientados de feldspato potássico. Nas zonas superiores, as rochas são equigranulares e os enclaves e megacristais são raros. Entre esses dois extremos, há uma zona de transferência, também rica em megacristais orientados, onde a presença de enclaves se restringe a faixas que originalmente constituíram canais de transporte de magma

Higgins (1999) também interpreta acumulados de feldspato potássico lineares no granodiorito de Cathedaral Peak, Califórnia como canais “fósseis” de mobilização de magma. Ao associar dados de distribuição granulométrica, análises químicas, texturas e relações de campo, conclui que os megacristais foram gerados a partir do crescimento de cristais préexistentes, em sistemas próximos ao liquidus. Em seu modelo, os primeiros cristais se formariam durante o resfriamento do corpo magmático ascendente e, com a interrupção do movimento, o corpo sofreria queda na taxa de resfriamento, gerando uma elevação momentânea de temperatura, seguida de resfriamento lento.

$\mathrm{O}$ estancamento do corpo favoreceria a formação de megacristais por meio da difusão de material através do liquido residual. Cristais de feldspatos potássico disseminados teriam seus componentes dissolvidos, alimentando o crescimento de unidades de maior tamanho. Tal modelo se contrapõe à conclusão de Vernon (1986) sobre a formação de megacristais de feldspato potássico que, em sua revisão literária, o autor conclui serem esses formados por cristalização direta do magma, com crescimento favorecido pelo espaço livre e pela abundância de componentes na fase liquida, descartando hipóteses de crescimento pós-magmático.

Segundo Vernon, feições que podem ser observadas macroscopicamente, como hábito idiomórfico, ausência de deformação e orientação por fluxo, como observado em Pedra de Guaratiba, são características compatíveis com cristalização a partir de fusão.

Johnson \& Glazner (2010) afirmam, contudo, que a ideia clássica de que megacristais idiomórficos de feldspatos potássico crescem livremente quando envolvidos por fusão, enquanto cristais xenomórficos constituem fases tardias, não é mais válida diante de dados experimentais que demonstram que cristais idiomórficos podem sobrecrescer cristais pré-existentes.

De acordo com os autores, estudos experimentais e teóricos comprovam que, em condições de aquecimento, a taxa de fusão dos cristais menores é superior à dos maiores, pois a diferença de energias de superfície entre cristais de dimensões distintas leva a quebra do menor para suprir o maior.

Assim, de forma semelhante à proposta de Higgins (1999), os cristais de menor dimensão seriam dissolvidos em fases de reaquecimento, promovendo o crescimento de megacristais e empobrecendo a matriz em feldspato potássico.

Tal ajuste textural e químico produziria várias feições atribuídas, em corpos bandados, a ação da gravidade. Em condições de queda de temperatura, por outro lado, o crescimento é linear para grãos de todos os tamanhos. Com base nessas premissas, Johnson \& Glazner (2010) apresentam um modelo de formação de cumulados de megacristais de feldspato potássico da Suíte Intrusiva Tuolumne, Califórnia, que envolve crescimento induzido por fluidos magmáticos durante episódios de reaquecimento, quando o grau de cristalidade impede a movimentação dos cristais.

Apesar de constituírem diferentes modelos, as propostas de Higgins (1999), Moyen et al. (2010), Rocher et al. (2018) e Johnson \& Glazner (2010), possuem, em comum, a ideia de que a orientação e segregação de feldspato potássico resulta de fluxo ao longo de canais, com o desenvolvimento dos fenocristais favorecido por episódios de reaquecimento consequente do estancamento do corpo ou da circulação de fluidos, hipóteses que devem ser consideradas nos estudos envolvendo os granitos de Pedra de Guaratiba.

Penha (1984) registra uma faixa, também rica em enclaves e interpretada como zona de borda, que tem início em Barra de Guaratiba, a aproximadamente $10 \mathrm{~km}$ a leste da área aqui estudada, e que se estende até a Praia da Macumba, no Recreio dos Bandeirantes.

Essa área, entretanto, assim como Pedra de Guaratiba, é dominada por granitos leucocráticos, típicos de zonas mais internas de grandes maciços e incomuns em zonas de bordas (Jerran \& Petford, 2014).

Observa-se que, em Pedra de Guaratiba, a zona enriquecida em allanita coincide com a 
faixa rica em enclaves, o que poderia resultar da ação de fluidos termais, mais suscetíveis a circulação nessa zona de maior permeabilidade.

Allanita possui elementos terras raras (ETRs) como constituintes essenciais (Gieré, 2004) e várias pesquisas associam sua formação à mobilização desses elementos por fluidos aquosos nos estágios tardios de cristalização do corpo ígneo. No processo, os fluidos retiram ETR de allanita primária, dando origem à allanita hidrotermal que ficam concentradas em algumas regiões do corpo ou em pegmatitos (Morin, 1977; Jiang et al., 2003; Anemburg et al., 2015).

Convêm destacar, ainda, que as Praias de Pedra de Guaratiba eram conhecidas desde os anos de 1950 por suas propriedades terapêuticas, advindas da riqueza em monazita de sua lama, e que esse mineral, assim como allanita, gera halos pleocróicos na rocha hospedeira. Dessa forma, uma prospecção sistemática para avaliação da possibilidade dos granitos como fonte de monazita é recomendável.

\section{CONSIDERAÇÕES FINAIS}

O trabalho aqui apresentado vem suprir a carência de dados detalhados de campo na região de Pedra de Guaratiba, um bairro do Rio de Janeiro em franco processo de expansão urbana. Durante a realização desse trabalho, muitos dos afloramentos estavam em vias de serem obliterados por construções em andamento e talvez não possam mais ser acessados em um futuro breve, o que demonstra a urgência em proceder-se ao estudo dessa área.

O Granito Pedra de Guaratiba possui variações texturais e granulométricas não representativas em mapa, e nas quais é possível reconhecer todas as fácies descritas por Porto Junior (1994) para a Unidade Pedra Branca. A Fácies Bandada é dominante e representada por rochas com cristais orientados de microclina tabulares, leitos de biotita e acamamento definido por variações granulométricas e/ou conteúdo de megacristais.

Os contatos entre as fácies são transicionais e as relações de campo apontam para processos de segregação mecânica na individualização das fácies, com o Granito Equigranular ocorrendo como produto de segregação, formando camadas ou bolsões adjacentes aos enclaves. A persistente estruturação linear de megacristais, as foliações definidas por bandamento, a geometria dos enclaves, e a própria configuração alongada do conjunto Serra da Capoeira Grande e Morro do Silvério, favorecem as hipóteses de fluxo sob a influência de processos cisalhantes e de existência de canais fósseis.

Entretanto, a região corresponde a menos de $10 \%$ da área aflorante do Maciço da Pedra Branca, sendo necessários estudos mais detalhados envolvendo a distribuição e o comportamento das zonas de enclave ao longo de todo o maciço. Os modelos propostos por Higgins (1999), Moyen et al. (2010), Rocher et al. (2018) e demais autores somente poderão ser avaliados após o mapeamento detalhado de todo o maciço e estudos complementares de seus aspectos químicos e estruturais.

Por fim, os dados de campo aqui apresentados revelam o potencial da região de Guaratiba para o desenvolvimento de estudos mais aprofundados relacionados à ocorrência de enclaves, fluxo magmático e processos hidrotermais que, integrados ao conjunto de dados do Maciço da Pedra Branca, permitirão uma melhor compreensão de sua história geológica.

\section{REFERÊNCIAS}

ALMEIDA, S. Reconhecimento da Mineração como atividade relevante na História da Fazenda Santa Cruz. In: SIMPÓSIO BRASILEIRO DE PATRIMÔNIO GEOLÓGICO, III. Lençóis. 2015. Resumos expandidos...Lençóis: Sociedade Brasileira de Geologia, 2015, p. 541-544.

ANEMBURG, M.; KATZIR, Y.; RHEDE, D.; JÖNS, N.; BACH, W. Rare earth element evolution and migration in plagiogranites: a record preserved in epidote and allanite of the Troodos ophiolite. Contributions to Mineralogy and Petrology, v. 169, 25 p., 2015. Disp. em: http://doi.org/10.1007/s00410-015-1114-y.

FERRARI, A.L. Evolução Tectônica do Gráben da Guanabara. São Paulo, 2001. 412 p. Tese (Doutorado), Universidade de São Paulo.

GIERÉ, R. \& SORENSEN, S.S. Allanite and other REE-rich epidote-group minerals. In: Epidotes LIEBSCHER, A. \&
FRANZ, G., (eds). Reviews in Mineralogy and Geochemistry, v. 56, p. 431-493, 2004.

HELMBOLD, R.; VALENÇA, J.G.; LEONARDO JR. O.H. Mapa geológico do Estado da Guanabara. Escala 1: 50.000, 1965.

HIGGINS, M.D. Origin of megacrysts in granitoids by textural coarsening: a crystal size distribution (CSD) study of microcline in the Cathedral Peak granodiorite, Sierra Nevada, California. Geological Society of London Spec. Publ., v. 168, p. 207-219, 1999.

JERRAN, D. \& PETTFORD, N. Descrição de Rochas Ígneas. Tradução de Ana Maria Pimental Mizusaki e Rualdo Menegat. Bookman. 2a. Ed. 264 p. 2014

JIANG, N.; SUN, S; CHU, X; MIZUTA, T; ISHIYAMA, D. Mobilization and enrichment of high-field strength elements during late- and post-magmatic processes the Shuiquangou 
syenitic complex, Northern China. Chemical Geology, v. 200, p. 117-128, 2003

JOHNSON, B.R. \& GLAZNER, A.F. Formation of K-feldspar megacrysts in granodioritic plutons by thermal cycling and latestage textural coarsening. Contributions to Mineralogy and Petrology, v. 159, p. 599-619, 2010.

MORIN, J.A. Allanite in granitic rocks of the Kenora-Vermilion Bay area, Northwestern Ontario. Canadian Mineralogist, v. 15, p. 297-302, 1977.

MOYEN. J.F.; NEDELEC, A.; MARTIN, H.; MUDLAPPA, J.; JAYANANDA, M. Syntectonic granite emplacement at different structural levels: the Closepet granite, South India. Journal of Structural Geology, v. 25, p. 611-63, 2010.

PENHA, H.M. Geologia do Maciço Pedra Branca. Rio de Janeiro, RJ. Anais da Academia Brasileira de Ciência, v. 53, p. 355356, 1984.

PINOTTI, L.P.; D'ERAMO, F.J.; WEINBERG, R.F.; DEMARTIS, M.; TUBÍA, J.M.; CONIGLIO, J.E.; RADICE, S.; MAFFINI, M.N.; ARAGÓN, E. Contrasting magmatic structures between small plutons and batholiths emplaced at shallow crustal level (Sierras de Córdoba, Argentina. Journal of Structural Geology, v. 92, p. 46-58, 2016.

PIRES, F.R.M.; VALENÇA, J.G.; RIBEIRO, A. Multistage generation of granite in Rio de Janeiro, Brazil. Anais da Academia Brasileira de Ciência, v. 54, p. 563-574, 1982.

PORTO JUNIOR, R. Petrologia das rochas graníticas das
Serras da Pedra Branca e Misericórdia, município do Rio de Janeiro, RJ, Brasil. Rio de Janeiro, 1994. 222 p. Dissertação (Mestrado). Universidade Federal do Rio de Janeiro.

PORTO JUNIOR, R. Petrogênese das rochas do Maciço da Pedra Branca, Rio de Janeiro. Rio de Janeiro, 2004. 231 p. Tese (Doutorado). Universidade Federal do Rio de Janeiro.

ROCHER, S.; ALASINO, P.H.M.; GRANDE, M.M.; LARROVEREA, M.A., PATERSON, S.R. K-feldspar megacryst accumulations formed by mechanical instabilities in magma chamber margins, Asha pluton, NW Argentina Journal of Structural Geology, v. 112, p.154-173, 2018.

VERNON, R.H. K-feldspar megacrysts in granites; phenocrysts, not porphyroblasts. Earth Science Reviews, v. 23, n. 1, p. 163, 1986.
Submetido em 10 de julho de 2019 Aceito para publicação em 5 de maio de 2020 